\title{
Introduction: forensic science, evidential reliability and institutional reform
}

\section{Paul Roberts and Michael Stockdale}

\section{GENESIS}

This volume arises from a longstanding collaboration between scholars associated with the Northumbria Centre for Evidence \& Criminal Justice Studies (NCECJS), part of Northumbria Law School, Northumbria University, in Newcastle-upon-Tyne. Directed since its founding by Michael Stockdale, NCECJS celebrated its tenth anniversary in October 2016. The project was catalysed by a Modern Law Review-sponsored workshop on The Reliability of Expert Evidence in Criminal Proceedings hosted by NCECJS in 2010, which focussed on discussion of the Law Commission's recently published consultation paper on the admissibility of expert evidence. ${ }^{1}$ The editors and several eventual contributors met here for the first time and, as lively discussion spilled over from the final session of the day into a long and congenial dinner, the idea of producing a collaborative work exploring contemporary issues in forensic science and expert witness testimony was hatched. As the project evolved and took on more definite shape, through a series of further meetings and in response to emerging events and rapidly changing policy and regulatory environments, the twin themes of evidential reliability and institutional reform emerged as its fulcrum. The last decade has witnessed significant adjustments to criminal procedure in many legal jurisdictions, including England and Wales, coupled with ongoing controversy surrounding the validity of many traditional forensic science techniques. Against this dynamic backdrop, this volume explores the pressing issue of whether the reliability of forensic science and other expert evidence may be enhanced through recent, or further, reforms of institutional arrangements

1 Law Commission Consultation Paper No 190, The Admissibility of Expert Evidence in Criminal Proceedings in England and Wales (London, TSO, 2009). 
for regulating the generation, presentation, testing and reliance on scientific evidence in criminal proceedings.

In this editorial Introduction, we briefly flesh out the legal, forensic science and policy contexts supplying the motivation and intellectual moorings for this study, and provide synoptic tasters of the 13 chapters comprising the volume. Featuring contributions from forensic scientists and policymakers, as well as from legal scholars, the volume consciously adopts an interdisciplinary approach bringing legal doctrine and practice into productive dialogue with scientific methodology, regulatory frameworks, sociological analysis and normative theoretical foundations. Comparative perspectives, extending to transnational data-sharing and mutual judicial assistance, are another prominent theme in the following pages, drawing on experiences from across, and beyond, the common law world.

\section{EVIDENCE LAW, SCIENCE AND POLICY}

Reflecting on the medium-term prospects of common law evidence in the last years of the twentieth century, the distinguished comparativist Mirjan Damaška wrote:

To consider the future, in the closing years of the twentieth century, is largely to talk about the creeping scientization of factual inquiry. In the wake of stupendous scientific and technological advances made over the past fifty years, new methods of establishing facts have begun to compete with traditional fact-finding ... With increasing frequency, then, courts are confronted with complex scientific and technical information ... Let there be no mistake. As science continues to change the social world, great transformations of factual inquiry lie ahead for all justice systems. ${ }^{2}$

This prophetic statement has lost none of its resonance in the intervening two decades. Not only has forensic science evidence become a central feature of modern criminal litigation in England and Wales and in many other jurisdictions, through the development of existing techniques (eg Low Template DNA profiling') and the advent of new ones (eg 'digital

2 Mirjan R Damaška, Evidence Law Adrift (New Haven, Yale University Press, 1997) 143-4, 151.

3 See $R$ v Reed and Reed; $R$ v Garmson [2010] 1 Cr App R 23, [2009] EWCA Crim 2698; Paul Roberts, 'LTDNA Evidence on Trial' (2016) 7 Frontiers in Genetics Article 180. 
forensics'4), it has also prompted widespread anxiety about misuses of unreliable expert evidence potentially contributing to serious miscarriages of justice. ${ }^{5}$ After a wide-ranging review of forensic science provision in the USA, the influential National Research Council of the National Academies reached the alarming conclusion that '[i]n a number of forensic science disciplines, forensic science professionals have yet to establish either the validity of their approach or the accuracy of their conclusions, and the courts have been utterly ineffective in addressing this problem' 6 Even the accuracy of fingerprints has been called into question, following high-profile cases of alleged misattribution in the USA (Mayfield) and Scotland (McKie). ${ }^{7}$

These messages have more recently been reinforced by the (US) President's Council of Advisors on Science and Technology (PCAST) Report on Forensic Science in Criminal Courts, ${ }^{8}$ which contains a raft of practical recommendations for improving the quality of forensic science in both the investigative and the adjudicative phases of criminal process. Meanwhile, following extensive review by the Law Commission, ${ }^{9}$ English criminal procedure law regulating the admissibility and interpretation of expert evidence at trial has undergone significant modification (albeit by a rather indirect route). ${ }^{10}$ It is therefore timely to pose, again, the perennial questions: just how reliable is forensic science (and expert

4 The 'shift to digital', engendered by '[t]he rapid growth and development of digital technology', is recognised as creating 'unique challenges; from the sheer quantity of digital data, to new forms of encryption and the increasing use of cloud storage': Home Office, Forensic Science Strategy, Cm 9217 (March 2016) 6,8 .

5 Generally, see Paul Roberts (ed), Expert Evidence and Scientific Proof in Criminal Trials (Farnham, Surrey, Ashgate, 2014); Paul Roberts, 'Forensic Science and Criminal Justice' in Anthea Hucklesby and Azrini Wahidin (eds), Criminal Justice, 2nd edn (Oxford, Oxford University Press, 2013).

6 National Research Council, Strengthening Forensic Science in the United States: A Path Forward (Washington DC, National Academies Press, 2009) 1-14.

7 See eg Simon A Cole and Andrew Roberts, 'Certainty, Individualisation and the Subjective Nature of Expert Fingerprint Evidence' [2012] Crim LR 824; Jennifer L Mnookin, 'The Validity of Latent Fingerprint Identification: Confessions of a Fingerprinting Moderate' (2008) 7 Law, Probability and Risk 127.

8 President's Council of Advisors on Science and Technology, Forensic Science in Criminal Courts: Ensuring Scientific Validity of Feature-Comparison Methods (Washington DC, Executive Office the US President, 2016).

9 Law Commission, Expert Evidence in Criminal Proceedings in England and Wales, Law Com No 325 (London, TSO, 2011).

10 Tony Ward, "'A New and More Rigorous Approach" to Expert Evidence in England and Wales?' (2015) 19 International Journal of Evidence \& Proof 228. 
evidence more generally)? To what extent do existing institutional arrangements promote effective generation, presentation, testing and reliance on forensic science evidence and expert witness testimony in criminal trials?

Reliability is the foundation stone of all judicial evidence. The verdict of a criminal court cannot be just if the evidence on which it is based is, or might well have been, unreliable. This is a primary tenet of rationality in criminal adjudication. Unreliable evidence is a direct cause of miscarriages of justice. Wrongful convictions of the innocent are often attributable to unreliable evidence. Unreliable evidence can also lead to the erroneous acquittal of the guilty, or a failure to detect, prosecute or bring offenders to trial in the first place. These elementary observations apply with particular force to forensic science evidence and expert witness testimony. Scientific evidence is often highly probative and rightly regarded as compelling. Yet precisely because scientific evidence has such a - generally speaking, well-merited - reputation for objectivity and accuracy, the scope for unreliable science to derail, divert or damage the administration of justice is accentuated.

If there are serious questions to be answered about the methodological foundations of forensic science and the epistemic adequacy of its evidential uses, it becomes vital to know what can realistically be done to enhance the reliability of scientific evidence and thereby promote the interests of justice. This is not simply a matter of tinkering with trial procedures and rules of evidence, important though they are for the quality of criminal adjudication in those - small minority - of prosecutions producing contested criminal trials. Addressing such questions demands a more comprehensive institutional approach, examining the ways in which scientific evidence is generated and utilised in police investigations and pre-trial processes, as well as investigating its impact on factfinders in criminal trials. This calls for interdisciplinary inquiry informed by forensic science, regulatory, social science and philosophical perspectives, no less than criminal jurisprudence. Moreover, to the extent that technological and structural issues affecting the reliability of forensic science and expert witness testimony reproduce themselves (with local institutional variations and inflections) in legal jurisdictions around the world, these inquiries will be enriched by a range of comparative perspectives. ${ }^{11}$ From the point of view of criminal proceedings in

11 It has been noted that 'beliefs regarding the use of scientific evidence in the criminal justice system are mainly shaped by Anglo-Saxon scholars, who produce the majority of (or the better disseminated) publications in the field': 
England and Wales, international experience represents a treasure house of normative good practice and cautionary tales for policymakers. It is also the institutional backdrop to transnational forensic data-sharing and mutual judicial cooperation, ${ }^{12}$ which is set to intensify whatever 'Brexit means Brexit' actually turns out to mean.

\section{SYNOPSIS}

In Chapter 1 of this book, Paul Roberts surveys the current forensic science landscape, from the perspective of an English legal scholar. His primary objective is to 'make sense' of this massive, diverse, fragmented and somewhat contested terrain. Having listed no fewer than 20 different ways in which forensic science evidence has been viewed as problematic, Roberts proceeds to elucidate the epistemological grounds for rational reliance on expert evidence and to consider the structural properties and resilience of the regulatory and procedural frameworks which govern this type of evidence in England and Wales. He then turns his attention to the 'intellectual resources' of 'forensic science', understood expansively to include models of evidential interpretation and frameworks for structuring inferential reasoning (including 'Bayesian' approaches). Roberts stresses the complexity and dynamism of the regulatory challenge of guaranteeing the reliability of forensic science evidence. Legal scholars have tended to focus on doctrinal issues, especially the task of formulating suitable evidentiary rules to regulate the admissibility of forensic science evidence in contested trials. Further reflection quickly demonstrates that admissibility is not the only doctrinal question posed by forensic science (and other expert) evidence; and moreover, doctrinal questions barely scratch the surface of the broader and deeper institutional, scientific, socio-legal and jurisprudential 'problematic' of forensic science.

The question of evidential reliability is taken up by Gary Edmond in Chapter 2, who reviews and summarises recent literature challenging the validity of many forensic science techniques which are routinely

Joëlle Vuille, 'Admissibility and Appraisal of Scientific Evidence in Continental European Criminal Justice Systems: Past, Present and Future' (2013) 45 Australian Journal of Forensic Sciences 389.

12 See further, Tim J Wilson, 'Criminal Justice and Global Public Goods: The Prüm Forensic Biometric Cooperation Model' (2016) 80 Journal of Criminal Law 303. 
deployed in criminal proceedings. Edmond exposes the yawning intellectual and practical gulf between recent authoritative assessments of the validity of modern forensic sciences and the admissibility standards applied by common law courts in relation to (ostensibly) scientific evidence. Although some marginal techniques have been seriously discredited, the principal methodological implication of these critical reassessments for commonly encountered 'pattern comparison' forensic specialisms - fingerprinting, footwear marks, ear-prints, tyre marks, glass, soil, hair, handwriting, fibres, voice and digital images, and the like - is more nuanced. It is not so much that these techniques are known to produce unreliable results: rather, their reliability is insufficiently known and not properly demonstrable by existing data and scientific research, unquantifiable or at least presently unquantified. As Edmond shows, however, common law courts have not in general been receptive to challenges to the methodological credentials of traditional forensic sciences, even when critical reports and data have been presented to them. Judges have preferred instead to fall back on jurisprudential proxies for evidential reliability, such as a history of judicial reliance in previous cases or favourable admissibility determinations in other jurisdictions, which seem curiously estranged from scientific standards of validity and reliability. These judicial strategies, characterised by Edmond as 'deflection and denial', enable criminal courts to maintain their largely proadmissibility stance towards forensic science evidence. Since most of this evidence is adduced by the prosecution, judicial practice has worrying implications for the evidential soundness of criminal convictions and the risk of miscarriages of justice.

A notable feature of Edmond's powerful critique is that it is not confined only to one legal jurisdiction. Chapter 2 briefly reviews case law and judicial practice in the USA, England and Wales, Scotland, Canada and Australia, identifying remarkably similar trends in the jurisprudence of expert evidence and consistent judicial attitudes towards forensic science. Edmond seems to be describing structural dimensions of common law reasoning and features of judicial culture which transcend domestic jurisdiction. In addition to its significance for legal policymaking, this analysis introduces the book's thematic contribution to the broader jurisprudential project of 'common law comparativism'. ${ }^{13}$ The task of calibrating legal principles of evidential reliability to comport with rigorous standards of scientific validity implicates basic institutional

13 As explained and exemplified in Paul Roberts and Jill Hunter (eds), Criminal Evidence and Human Rights (Oxford, Hart Publishing, 2012). 
structures, and is in some respects methodological and transnational. Orthodox normative frameworks and embedded procedural traditions may not be enough to tackle it satisfactorily without tapping into an expanded range of institutional resources.

Tony Ward, in Chapter 3, broadly accepts Edmond's diagnosis of the problem $^{14}$ but offers a somewhat different prescription. Ward argues from within a paradigm of 'civic epistemology', according to which truthproducing institutional processes - such as criminal adjudication - must answer to shared principles of political morality. For many common law jurisdictions, including England and Wales, the jury plays a vital, constitutional, role in justifying public findings of criminal guilt and the infliction of state punishment on offenders. Given that common law juries classically deliberate in secret and pronounce unreasoned verdicts, so that the actual grounds of their decision-making cannot be scrutinised, trial judges are charged with the responsibility of ensuring that only evidentially well-founded accusations are presented to the jury in the first place. Where there is 'no case to answer', the prosecution is halted in its tracks and results in a judge-directed acquittal. ${ }^{15}$ The rationality of criminal verdicts is in this way pre-authenticated to some extent. If the process operates as intended, juries are structurally able to convict only in cases in which they could reasonably convict. ${ }^{16}$ The law of criminal procedure, notably encompassing the complex admissibility doctrines for which common law trial systems are renowned (and sometimes pilloried), supplies the principal institutional mechanisms through which trial judges discharge their essential screening function. ${ }^{17}$

Extrapolated to the specific context of forensic science and other expert evidence, these principles condense into what Ward calls 'the Davie principle', ${ }^{18}$ which demands that juries must always make up their own minds, even in relation to scientific and technical matters in which they have no personal expertise. This precept would seem plainly irrational, were it not for the fact that the question about which the jury

14 Also see Gary Edmond, 'Is Reliability Sufficient? The Law Commission and Expert Evidence in International and Interdisciplinary Perspective (Part 1)' (2012) 16 International Journal of Evidence \& Proof 30.

${ }_{15} R v$ Galbraith [1981] 1 WLR 1039, CA. The precise boundaries of judicial intervention to dismiss proceedings are admittedly unclear and somewhat controversial: see eg $R v F(S)$ [2012] QB 703, [2011] EWCA Crim 1844.

$16 \quad R$ v Brennan [2015] 1 WLR 2060, [2014] EWCA Crim 2387.

17 See Paul Roberts and Adrian Zuckerman, Criminal Evidence, 2nd edn (Oxford, Oxford University Press, 2010) esp ch 2.

18 Following Davie v Edinburgh Magistrates [1953] SC 34. 
has to decide is not the same as the one requiring expert knowledge or skill. ${ }^{19}$ The question for the jury is: what is the meaning and value of all the evidence, taken in its totality, in relation to contested questions of fact? More instrumentally, has the prosecution discharged its demanding burden of proof in relation to the specified charges? The expert witness's job is to supply the jury with information and warranted conclusions on specialist topics, so that the jury can use that information to reach a verdict in answer to its own institutionally allocated questions. The Davie principle admonishes that expert witnesses must never upstage the jury, by substituting answers to specialist questions of the first type for evidentially holistic, ${ }^{20}$ and inescapably normative, ${ }^{21}$ answers to disputed questions of fact.

Ward suggests that this theoretical model of criminal adjudication, grounded in civic epistemology, has significant implications for how the admissibility of forensic science evidence should be regulated in practice. In particular, Ward argues that admissibility determinations always need to be contextualised and related to the entirety of the evidence in the case. He is consequently sceptical of excessively categorical approaches to scientific validity as a precondition of legal admissibility. For one thing, consideration must be given to the - possibly erroneous conclusions that juries might draw in the absence of forensic science evidence. $^{22}$ Sometimes, as the illustrative reported cases Chapter 3 discusses show, it is not really possible to present competing case narratives fairly without mentioning forensic findings, even if their scientific status may be questionable. ${ }^{23}$ Ward concludes that existing

19 Generally, see Douglas Walton, Appeal to Expert Opinion: Arguments from Authority (University Park PA, Penn State University Press, 1997).

20 For conceptual elucidation, see Michael S Pardo, 'Juridical Proof, Evidence, and Pragmatic Meaning: Toward Evidentiary Holism’ (2000) 95 Northwestern University Law Review 399.

21 See Paul Roberts (ed), Theoretical Foundations of Criminal Trial Procedure (Farnham, Surrey, Ashgate, 2014).

22 On 'inferences from absence' and 'missing evidence', see Alex Biedermann and Joëlle Vuille, 'Digital Evidence, "Absence" of Data and Ambiguous Patterns of Reasoning' (2016) 16 Digital Investigation S86; Elliot Sober, 'Absence of Evidence and Evidence of Absence: Evidential Transitivity in Connection with Fossils, Fishing, Fine-Tuning and Firing Squads' (2009) 143 Philosophical Studies 63; Douglas Walton, 'Nonfallacious Arguments from Ignorance' (1992) 29 American Philosophical Quarterly 381; Dale A Nance, 'Missing Evidence' (1991) 13 Cardozo Law Review 831.

23 Also see Edward J Imwinkelried, 'Dealing with Supposed Jury Preconceptions about the Significance of the Lack of Evidence: The Difference between the 
common law principles of admissibility are essentially sound, whilst conceding that their application to specific instances of forensic science evidence in particular cases might leave much to be desired.

Roberts, Edmond and Ward all discuss the possibility of employing more informal standards, such as codes of practice and regulatory guidance, as practical supplements to legal doctrine to promote the reliability of forensic science evidence. The general topic of regulatory standards in forensic science is authoritatively addressed by the current Forensic Science Regulator, Gillian Tully, in Chapter 4. Having summarised the origins, role and jurisdiction of the Regulator, Tully describes in detail the ongoing work of her Forensic Science Regulation Unit ${ }^{24}$ in developing an effective regulatory regime for ensuring high quality forensic science provision to the administration of criminal justice in England and Wales.

The UK forensic landscape is complex and diverse, comprising a 'mixed economy' of public and commercial providers and a plethora of scientific sub-disciplines and techniques. For a variety of historical and cultural reasons, some areas of forensic science practice are more receptive to regulatory oversight than others, and some disciplinary fields have entrenched institutional power to resist it in favour of traditional practices and familiar habits of mind. Tully characterises her overarching ambition as one of promoting 'a mature quality culture' across the forensic sciences. This would require a reflective appreciation that quality standards and audit need to be embedded in routine forensic science practice and should be recognised as integral to the basic constitution and rationale of the enterprise. A mature quality culture should underpin public faith in the work of forensic laboratories and the professional integrity of individual forensic scientists. It is the diametric opposite of the attitude, sometimes encountered in managerial and policy circles, that quality standards are a bolt-on afterthought, merely requiring periodic box-ticking, and may not be affordable anyway in times of austerity. Incidents such as the recent Randox scandal, placing '[t]housands of criminal cases under review' owing to the possibility that 'forensic lab

Perspective of the Policymaker and that of the Advocate' (2010) 27 Thomas M Cooley Law Review 37; Corinna Kruse, 'Legal Storytelling in Pre-Trial Investigations: Arguing for a Wider Perspective on Forensic Evidence' (2012) $31 \mathrm{New}$ Genetics and Society 299; Brian J Foley, 'Until We Fix the Labs and Fund Criminal Defendants: Fighting Bad Science with Storytelling' (2007) 43 Tulsa Law Review 397.

24 www.gov.uk/government/organisations/forensic-science-regulator (accessed 31 January 2018). 
results may have been manipulated', ${ }^{25}$ graphically demonstrate - if further demonstration were truly needed - that quality failures in forensic science can be far more expensive, and not merely in financial terms, than robust quality assurance. ${ }^{26}$

Observing the intimate connection between the quality of forensic science services and the reliability of forensic science evidence, Tully expounds the work of standard-setting through the prism of four cardinal principles of interpretation: balance, logic, robustness and transparency. ${ }^{27}$ These generic principles are further elucidated and concretised in the Regulator's detailed Codes of Practice and Conduct, as Chapter 4 explains. On the other side of the equation, risk factors must also be considered. For example, contextual bias is the enemy of balance, just as fallacious reasoning defies logic, inadequate validation undermines robustness, and poor record keeping or incomplete disclosure erodes transparency. Tully concludes her whistle-stop review by drawing attention to institutional factors, largely beyond the Regulator's control, which are likely to have significant bearing on the success of regulatory initiatives. Tightening funding constraints, the viability and resilience of free market competition in forensic science provision, and the practical implementation of Streamlined Forensic Reporting (SFR) are identified as continuing areas of concern.

In Chapter 5, Sophie Carr, Angela Gallop, Emma Piasecki, Gillian Tully and Tim J Wilson focus specifically on DNA profiling and fingerprint evidence - collectively, 'bio-metrics' - in order to explore what they characterise as the 'reliability continuum'. Proceeding from the sharp observation that 'reliability' appears to take on different meanings in scientific and legal usage and thus lacks terminological stability in discussions of forensic science, this chapter elucidates the concept of evidential reliability in terms of a tripartite conception of 'scientific validity', comprising foundational validity, applied validity and evaluative

25 Hannah Devlin and Vikram Dodd, 'Thousands of Criminal Cases under Review', The Guardian, 22 November 2017; Martin Evans, 'Forensics Lab Tests Tampering Probe Identifies 10,000 Criminal Cases that Might Have Been Affected', The Telegraph, 21 November 2017; Lizzie Dearden, 'Convictions in Doubt as More than 10,000 Cases Could be Affected by Data Manipulation at Forensics Lab: Scandal has Caused Drug Driving Cases to be Dropped and Deaths Referred to the Court of Appeal', The Independent, 21 November 2017. 26 Also see Forensic Science Regulator, Annual Report: November 2016November 2017 (Birmingham, FSR, 2018) 6-8.

27 Drawing on Association of Forensic Science Providers, 'Standards for the Formulation of Evaluative Forensic Science Expert Opinion' (2009) 49 Science \& Justice 161. 
validity. All three dimensions of scientific validity must be satisfied, coherently with broader institutional influences, to establish the reliability of forensic science evidence. Carr and colleagues further suggest that the 'reliability continuum' presents 'liminal zones' in which the validity claims of particular types of scientific evidence are scrutinised and assessed, constituting a kind of institutional 'rite of passage' to establish epistemic trustworthiness for the purposes of decision-making in criminal proceedings. This original analytical framework is further elucidated through detailed application to fingerprinting and DNA profiling evidence. The chapter reviews the state of the art in these two prominent forensic specialisms, drawing attention to subjective factors and potential pressure points in disciplinary methods and working practices which circumscribe scientific validity and could potentially erode it. Carr and colleagues conclude by highlighting priority areas for further policy development, including devising standardised formats and terminology for expert reports and refining interpretational protocols.

With overlapping authorship, Chapter 6 extends a similar theoretical approach to forensic pathology evidence. Tim J Wilson, Adam Jackson, Angela Gallop and Emma Piasecki begin their chapter by summarising the current institutional context of forensic pathology services in England and Wales, and introducing the idea of 'critical trust' that has been developed in previous work. ${ }^{28}$ Forensic pathology resembles many of the other forensic specialisms discussed in this book, inasmuch as questions of methodological validity and procedural requirements such as full and timely disclosure of information (including potentially exculpatory findings) apply to all forms of scientific and other expert evidence utilised or adduced in criminal proceedings. However, the organisation and provision of forensic pathology services additionally presents more particularised difficulties, such as how to demarcate and manage the practical interface between coronial (non-criminal justice) and forensic postmortem examinations. Pathology sits within the general domain of medical science, and consequently operates according to its own professional standards, regulatory mechanisms and cultural norms which intersect with legal processes in distinctive ways. ${ }^{29}$ Forensic pathology is thus both like and unlike other forensic sciences.

28 Sophie Carr, Emma Piasecki, Gillian Tully and Tim J Wilson, 'Opening the Scientific Expert's Black Box: "Critical Trust" as a Reformative Principle in Criminal Evidence' (2016) 80 Journal of Criminal Law 364.

29 Also see Roger Smith, 'Forensic Pathology, Scientific Expertise and the Criminal Law' in Roger Smith and Brian Wynne (eds), Expert Evidence: 
These issues are further explored in Chapter 6 through two detailed 'case studies' of criminal appeals in which forensic pathology evidence played a pivotal role. These cases highlight the serious potential for miscarriages of justice when the reliability of pathology evidence is shaky or misinterpreted. Prosaic individual and institutional failings are often to blame, as the case studies demonstrate. A more profound diagnostic factor, Wilson and colleagues suggest, is the lingering cultural deference still routinely afforded to forensic pathologists, harking back to the days of celebrity medical witnesses such as Sir Bernard Spilsbury, ${ }^{30}$ who cultivated an aura of infallibility. Yet critical trust in pathology evidence should be earned, rather than automatically bestowed, through demonstrable reliability employing transparent procedures and appropriately rigorous testing. Criminal adjudication has plainly not always lived up to its epistemological pretensions, and Wilson and colleagues detect structural frailties lurking below the surface of individual errors in particular cases. Trusting to the professionalism of forensic pathologists, by bolstering their autonomy in casework decision-making, is advocated as one plausible strategy for enhancing the reliability and effectiveness of forensic pathology evidence.

The next chapter brings the discussion back to more familiar terrain for legal scholarship. Rather than revisiting common law precedents grappling with the admissibility of expert evidence, however, Michael Stockdale in Chapter 7 offers detailed exegesis on what he describes as 'the civil-criminal-family procedure rules trichotomy'. Part 19 of the Criminal Procedure Rules (and associated provisions of the consolidated Criminal Practice Directions) make cameo appearances in earlier (and later) chapters. Stockdale undertakes a more systematic analysis of procedural rules governing expert evidence, and one which is literally 'comparative' in drawing detailed parallels and highlighting many intriguing points of contrast between the separate sets of Rules produced for civil (private law), family and criminal proceedings in England and Wales. This is a novel approach, since although the Law of Evidence is

Interpreting Science in the Law (London, Routledge, 1989); H Johnson, 'The Pathologist as an Expert Witness' (1986) 54 Medico-Legal Journal 26.

30 On 'the rise of the medical detective', see Carol AG Jones, Expert Witnesses: Science, Medicine and the Practice of Law (Oxford, Oxford University Press, 1994) ch 5. Also see Keith Simpson, 'Medicine v The Law: Part Heard' (1971) 3 Australian Journal of Forensic Sciences 114, 118 (quoting Alec Bourne remarking that 'I have the greatest respect for Sir Bernard when he speaks as a pathologist, but when he dares to give an opinion about the treatment of a living woman, I would regard it with contempt'). 
regarded as a unified subject in orthodox common law thinking, ${ }^{31}$ procedural law - somewhat curiously - has always been disaggregated into separate spheres of Civil Procedure ${ }^{32}$ and Criminal Procedure. ${ }^{33}$

Having explained the Rules' legislative origins and status, Stockdale painstakingly works through their detailed provisions, addressing such matters as expert witnesses' competence and professional duties, the contents of experts' reports, issues of objectivity and bias, questions of selection and 'expert shopping', and the role of trial judges in regulating expert evidence, including admissibility standards. Readers will be left in no doubt that these procedural Rules have important practical bearing on just about all the issues that are frequently discussed in jurisprudentially more elevated terms, featuring primary legal sources. Chapter 7 then considers how practical innovations such as arranging pre-trial discussions between experts, ${ }^{34}$ reliance on written reports as admissible evidence (which would be hearsay at common law), ${ }^{35}$ and non-partisan single joint expert reports might be regarded as eroding - or even replacing - the procedural safeguards which have traditionally been thought to guarantee evidential reliability in adversarial legal systems. Some of the issues this discussion brings to light, such as the problems associated with the MedCo system for appointing experts in tort claims for 'whiplash' injuries, ${ }^{36}$ seem quite localised to particular spheres of

31 For a revisionist (or heretical) reinterpretation, see Paul Roberts, 'Five Foundational Fallacies of Common Law Evidence' (2019), forthcoming; as presaged by AAS Zuckerman, The Principles of Criminal Evidence (Oxford, Clarendon Press, 1989).

32 See eg Adrian Zuckerman, Zuckerman on Civil Procedure: Principles of Practice, 3rd edn (London, Sweet \& Maxwell, 2013).

33 See eg John Sprack, A Practical Approach to Criminal Procedure, 15th edn (Oxford, Oxford University Press, 2015).

34 Not an entirely new idea: see Paul Roberts, 'Forensic Science Evidence after Runciman' [1994] Criminal Law Review 780.

${ }^{35} R$ v Abadom [1983] 1 WLR 126, CA; Rosemary Pattenden, 'Expert Opinion Evidence Based on Hearsay' [1982] Criminal Law Review 85. Now see Civil Evidence Act 1995, s 1 (declaring that '[i]n civil proceedings evidence shall not be excluded on the ground that it is hearsay'); Criminal Justice Act 1988, s 30; Criminal Justice Act 2003, ss 118 and 127 (creating circumscribed hearsay exceptions for expert evidence in criminal proceedings).

36 See www.medco.org.uk/home/how-it-works/ (accessed 31 January 2018); Ministry of Justice, Reducing the Number and Costs of Whiplash Claims: A Government Response to Consultation on Arrangements Concerning Whiplash Injuries in England and Wales, Cm 8738 (London, TSO, 2013), https://consult. justice.gov.uk/digital-communications/reducing-number-cost-whiplash/results/whip lash-response.pdf (accessed 31 January 2018). 
litigation practice. But the greater part of Stockdale's analysis targets more structural features of legal proceedings which operate across the jurisdictional 'trichotomy'. This convergent experience prompts Stockdale to question the many unexplained discrepancies in drafting and practice that currently differentiate the three procedural Rules regimes, raising the suspicion that such discrepancies lack rational explanation. $\mathrm{He}$ concludes by advocating more coordinated dialogue in the name of reducing complexity, increasing intelligibility, and sharing best practice across all three procedural jurisdictions - measures which would uniformly promote the reliability of expert evidence.

In Chapter 8, Liz Heffernan paves the way for more conventional styles of comparative scholarship, by exploring the law and practice of expert evidence in the Republic of Ireland. Modern Irish law is firmly rooted in the common law tradition, ${ }^{37}$ and this familial resemblance is very plain to see in the Law of Evidence and in relation to expert witnesses in particular. The historical evolution of Irish expert evidence law and the contemporary illustrations of reported Irish cases grappling with expertise, which Chapter 8 expounds, will resonate with British readers and common lawyers around the globe. Indeed, Irish law might be thought to represent the more authentic - or possibly, unreconstructed - common law position. The practical difficulties of assessing the reliability and probative value of expert evidence described by Heffernan are equally familiar. For example, Irish criminal courts, like their counterparts in other jurisdictions, have been called upon to assess the probative significance of toxicology, fingerprinting, document analysis and psychiatric evidence. More recently, Irish courts have had to educate themselves about the nature of DNA profiling evidence, and consider how best to express very small match probabilities to juries without giving the misleading impression that a 'match' is effectively conclusive proof of identity. ${ }^{38}$ (Automatic equation would be fallacious, for the reasons elucidated by Carr and colleagues in Chapter 5. ${ }^{39}$

Heffernan characterises the Irish courts' approach to expert evidence as piecemeal, pragmatic and susceptible to the institutional dynamics and happenstance of litigated cases; possibly a not too unkind description of common law method generally. However, systematic reform has been on

37 Albeit within a distinctive cultural setting and constitutional legal order: see eg John Jackson, 'Human Rights, Constitutional Law and Exclusionary Safeguards in Ireland' in Roberts and Hunter (eds), above n 13.

38 DPP $v$ Wilson [2017] IESC 54.

39 Also see Michael J Saks and Jonathan J Koehler, 'The Individualization Fallacy in Forensic Science Evidence' (2008) 61 Vanderbilt Law Review 199. 
the agenda in recent years, driven by the Irish Law Reform Commission. ${ }^{40}$ This is linked to a concern that faulty or misinterpreted expert evidence could be a source of miscarriages of justice in Ireland, influenced by the predominantly US critical literature on forensic science methodology, summarised by Edmond in Chapter 2 of this book. Reform should also, Heffernan argues, draw inspiration from the Irish constitutional tradition - now reinforced by European human rights law - in recognising meaningful opportunities to test and challenge forensic science and other expert evidence adduced by the prosecution as part of the accused's right to a fair trial. Safeguards operating in contested trials are only one dimension of comprehensive procedural fairness, which also extends to such matters as timely pre-trial disclosure by the prosecution and adequate funding for scientific experts to assist the defence. On the question of admissibility standards, Heffernan draws a more pluralistic lesson from international experiences. Rather than following other jurisdictions in embracing judicial gatekeeping as a formalised prerequisite to admissibility, Heffernan advocates a more flexible, contextualised judicial approach, but one firmly focussed on ensuring that expert evidence adduced in trials is actually reliable, and therefore genuinely relevant, to the proceedings. This 'simple but powerful truth', she suggests, could be reinforced by informal guidance specifying generic criteria of reliability to assist trial judges in their admissibility determinations; a proposal in tune with Stockdale's analysis of procedural rules in the preceding chapter.

Any comparative discussion of the admissibility of expert evidence which ignored the US Supreme Court's landmark decision in Daubert $v$ Merrell Dow ${ }^{41}$ would truly be Hamlet without the prince. Daubert has attracted profuse citation and critical commentary (for all we know, even in Denmark). ${ }^{42}$ In Chapter 9, Edward J Imwinkelried offers a jurisdictional insider's guide to Daubert's meaning and legacy for the US law and practice of expert evidence. On Imwinkelried's account, Daubert's enduring significance lies in the Supreme Court's explicit acknowledgement that scientific knowledge, and therefore expert testimony based on

40 Law Reform Commission, Report on Consolidation and Reform of Aspects of the Law of Evidence, LRC 117-2016 (Dublin, LRC, 2016), www.lawreform.ie/ news/report-on-consolidation-and-reform-of-aspects-of-the-law-of-evidence. 705. html (accessed 31 January 2018).

41 Daubert v Merrell Dow, 125 L Ed 2d 469; 113 S Ct 2786 (1993).

42 Westlaw lists 23,345 US case citations and 13,702 law review articles and secondary commentaries (14 February 2018). 
it, is always in principle fallible and falsifiable. ${ }^{43}$ Empirical science is not certain, but inherently probabilistic. Imwinkelried echoes previous critical evaluations that have queried Daubert's practical impact, especially in criminal cases. ${ }^{44}$ It may be that the reliability of established forensic sciences is not being scrutinised any more rigorously under Daubert's supposedly proactive judicial gatekeeping than it would have been - or in some US states, still is ${ }^{45}$ - being tested under the Frye 'general acceptance' standard ${ }^{46}$ (though Imwinkelried also stresses the practical significance of extending judicial gatekeeping to non-scientific types of expertise, which fell outside traditional interpretations of Frye). ${ }^{47}$ For Imwinkelried, however, this is not necessarily the headline story.

Imwinkelried develops his thesis by analysing drink-driving and road traffic accident cases in which toxicological or speed camera evidence posed questions of metrology (the science of measurement). Chapter 9 charts an evolution in judicial thought through four phases. At first, trial judges in thrall to a naïve conception of scientific certainty insisted that expert witnesses provide unequivocal conclusions and discrete values for measurements. Many expert witnesses played along, most notoriously in some sections of the fingerprinting community where only conclusions expressed as 'certain' were regarded, for a time, as professionally competent. Gradually, however, the irremediable uncertainty of scientific inference reasserted itself. In the second jurisprudential phase identified

43 Also see Bert Black, 'The Supreme Court's View of Science: Has Daubert Exorcised the Certainty Demon?' (1994) 15 Cardozo Law Review 2129.

44 See eg Susan D Rozelle, 'Daubert, Schmaubert: Criminal Defendants and the Short End of the Science Stick' (2007) 43 Tulsa Law Review 597; D Michael Risinger, 'Navigating Expert Reliability: Are Criminal Standards of Certainty Being Left on the Dock?' (2000) 64 Albany Law Review 99; Paul C Giannelli, “"Junk Science": The Criminal Cases' (1993) 84 Journal of Criminal Law and Criminology 105.

45 Daubert is a formal precedent only in federal court proceedings. Many states have adopted a version of Daubert as the governing admissibility standard in state evidence law, but a minority of states - including New York and California - have retained their own admissibility criteria (still) based on Frye.

46 Frye v US, 54 App DC 46, 47; 293 F 1013, 1014 (1923) (holding that "while courts will go a long way in admitting expert testimony deduced from a well-recognized scientific principle or discovery, the thing from which the deduction is made must be sufficiently established to have gained general acceptance in the particular field to which it belongs').

47 Kumho Tire Co v Carmichael, 119 S Ct 1167 (1999). For comparative discussion, see Paul Roberts, 'Tyres with a "Y": An English Perspective on Kumho Tire and its Implications for the Admissibility of Expert Evidence' (2003) 1(2) International Commentary on Evidence Article 5 (2 July 1999). 
by Imwinkelried, probabilistic qualifications ('probable', 'possible') became forensically acceptable, leading to a third phase in which bogus expressions of certainty were banished from courtrooms completely. Certainty now looked like bad science or partisan over-claiming by expert witnesses. The fourth and final phase is marked by courts expecting scientific experts to quantify their level of uncertainty, by supplying ranges of values and confidence intervals for calculated estimates, especially where legal consequences attach to particular measurements with precise thresholds (eg blood-alcohol concentrations in drink-driving prosecutions). In reality, of course, judicial approaches to the (un)certainty of scientific evidence have not evolved along a uniformly linear trajectory. Imwinkelried highlights elements of inconsistency between courts and across state jurisdictions; there are always laggards, and technological innovation perpetually confronts trial judges with new challenges moving forward. Looking past transient distractions, Imwinkelried encourages us to take the longer view and the higher road, to arrive at a better accommodation between the epistemological status of scientific evidence and the professional responsibilities of expert witnesses to tell the whole truth in court. If Daubert's ultimate legacy is the intellectual progress identified by Imwinkelried in Chapter 9, it will have earned its pre-eminent place in comparative jurisprudence.

In Chapter 10, Emma Cunliffe transports us further north to consider expert evidence law and law reform in Canada; a jurisdiction which possibly owing to its North American orientation and the influence on procedural law of its indigenous Charter of Rights and Freedoms ${ }^{48}-$ features less prominently in British legal scholarship than one might anticipate. Cunliffe reviews developments in Canadian case law on expert evidence since the mid-1990s and posits the emergence of a 'new paradigm' heralded, more or less, by the Canadian Supreme Court's pivotal decision in Mohan ${ }^{49}$ This new paradigm involves taking seriously the judicial responsibility to ensure that scientific evidence is reliable and has sound methodological underpinnings, even though it may have been ruled admissible on previous occasions. As Cunliffe describes, Canadian

48 See eg Christine Boyle and Emma Cunliffe, 'Right to Counsel during Custodial Interrogation in Canada: Not Keeping Up with the Common Law Joneses' in Roberts and Hunter (eds), above n 13.

${ }^{49} R$ v Mohan [1994] 2 SCR 9. For contemporary discussion, see Paul Roberts, 'Expert Evidence in Criminal Proceedings: More Lessons from North America' in Helen Reece (ed), Law and Science (Oxford, Oxford University Press, 1998) and 1 Current Legal Issues 175. 
law has developed its own idiosyncratic admissibility framework, comprising two sequential stages and multiple criteria, each of which has received judicial consideration and further elucidation in a series of appellate decisions.

Numerous parallels emerge between the Canadian experience surveyed by Cunliffe and the British, Australian, Irish and US law and practice dissected in earlier chapters. Perhaps unsurprisingly, whilst the precise contours of its doctrinal responses are uniquely Canadian the underlying theoretical, methodological and practical issues arising from scientific and other expert evidence in Canadian criminal proceedings substantially coincide with the problems addressed in other legal jurisdictions. Also by now familiar is the observable gap between judicial gatekeeping in jurisprudential theory and its rather less impressive reality, leading Cunliffe to question just how far the dominant paradigm has really shifted in Canadian trial practice. Indeed, several recent cases are held up to illustrate how Canadian judges may find it hard to break their bad old habits, such as accepting dubious proxies for scientific reliability and concocting evasive admissibility compromises, of the kind skewered by Edmond in Chapter 2 of this book. Cunliffe concludes that Canadian trial judges may need better training and more institutional support to complete the paradigm shift in regulating expert evidence signalled by the Supreme Court and translate its aspirations into tangible reality.

Common law comparativism is greatly enriched by including some of the lesser known or widely fêted common law jurisdictions in the conversation. It is really quite remarkable that a handful of dominant countries are typically allowed to stand in for 'the common law' tout court, and little wonder that scholars from emerging nations such as China easily equate a culturally dominant US law with the common law tradition. ${ }^{50}$ Salim Farrar and Mohd Munzil Muhamad in Chapter 11

50 Reflected, for example, in the remarkable influence of the US Federal Rules of Evidence in shaping recent debates surrounding procedural reforms in China: see John J Capowski, 'China's Evidentiary and Procedural Reforms, the Federal Rules of Evidence, and the Harmonization of Civil and Common Law' (2012) 47 Texas International Law Journal 455; Jia Li and Zhuhao Wang, 'A Trail to Modernity: Observations on the New Developments of China's Evidence Legislation Movement in a Global Context' (2014) 21 Indiana Journal of Global Legal Studies 683. More generally, see Máximo Langer, 'From Legal Transplants to Legal Translations: The Globalization of Plea Bargaining and the Americanization Thesis in Criminal Procedure' (2004) 45 Harvard International Law Journal 1; Ugo Mattei, 'A Theory of Imperial Law: A Study on US Hegemony and the Latin Resistance' (2003) 10 Indiana Journal of Global Legal Studies 383. 
contribute towards correcting this structural deficit in comparative procedural scholarship, by exploring expert evidence law and practice in Malaysia. Their starting point is a conception of Malaysia as a 'developmental state' with a legal procedural system inherited from its colonial past, 51 but now led by a government with ambitious plans for economic progress and modernisation, notably including technological innovations in the administration of justice. There has been significant investment in a new police forensic laboratory (partly with an eye to exploiting emerging opportunities in DNA profiling) and the creation of training programmes and facilities in order to develop a new cadre of scenes of crime officers (CSIs). The eternal forensic question posed by Farrar and Muhamad's discussion is whether legal structures and routine working practices in the conduct of criminal investigations, prosecutions and trials have managed to keep pace with technological innovations.

Farrar and Muhamad narrate a cautionary tale. On one level, it is the same story of limited funding for defence experts, deficiencies in legal education on technological topics (especially probability and statistics), and exaggerated judicial deference to scientific expertise that could be told about Western legal systems. To this extent, it echoes many of the preceding chapters' criticisms of contemporary criminal proceedings in Australia, Canada, Ireland and the USA, as well as finding clear parallels in the UK's legal jurisdictions. But there are also important points of contrast, as Farrar and Muhamad emphasise. Malaysia is not a civic or human rights-based liberal democracy. ${ }^{52}$ It does not boast robust procedural protections for suspects and the accused, and criminal justice policy is framed in the populist discourse of ensuring that criminals are caught and punished (with the death penalty for the worst offenders). In this social environment, procedural failings and weaknesses which beset criminal adjudication around the world are exacerbated and their impact and effects could be more pernicious. Farrar and Muhamad single out inadequate pre-trial disclosure and lawyers' and courts' lack of training in scientific methodology as particular risk factors for miscarriages of justice. Whilst these particular pinch-points might be alleviated by targeted reforms, they argue - more ambitiously - for the creation of a Criminal Cases Review Commission (CCRC) to undertake more systematic remedial scrutiny of potential wrongful convictions. If the UK's

51 In particular, the Evidence Act 1950 is a local statutory adaptation of Stephen's influential Indian Evidence Act.

52 Also see Salim Farrar, 'Degrading Searches and Illegally Obtained Evidence in the Malaysian Criminal Justice System' in Roberts and Hunter (eds), above $\mathrm{n} 13$. 
CCRCs represent a successful, if perennially controversial, ${ }^{53}$ model of institutional reform amenable to emulation in Malaysia, Farrar and Muhamad's Southeast Asian case study repays the comparative compliment by highlighting aspects of criminal procedure with uncomfortable resonances closer to home. ${ }^{54}$

In Chapter 12, Joëlle Vuille widens the comparative lens to consider the role of forensic science evidence in 'non-adversary' criminal justice systems; a term she prefers to 'inquisitorial', which is standard in the Anglosphere but puzzling to continental scholars. ${ }^{55}$ Whatever

53 For a variety of perspectives and a range of evaluations, see Carolyn Hoyle, 'Compensating Injustice: The Perils of the Innocence Discourse' in Jill Hunter, Paul Roberts, Simon NM Young and David Dixon (eds), The Integrity of Criminal Process (Oxford, Hart, 2016); Michael Naughton (ed), The Criminal Cases Review Commission: Hope for the Innocent? (Basingstoke, Palgrave, 2009); Peter Duff, 'Straddling Two Worlds: Reflections of a Retired Criminal Cases Review Commissioner' (2009) 72 Modern Law Review 693; Stephanie Roberts and Lynne Weathered, 'Assisting the Factually Innocent: The Contradictions and Compatibility of Innocence Projects and the Criminal Cases Review Commission' (2009) 29 Oxford Journal of Legal Studies 43; Hannah Quirk, 'Identifying Miscarriages of Justice: Why Innocence in the UK is Not the Answer' (2007) 70 Modern Law Review 759; Richard Nobles and David Schiff, 'The Criminal Cases Review Commission: Establishing a Workable Relationship with the Court of Appeal' [2005] Criminal Law Review 173; Graham Zellick, 'The Criminal Cases Review Commission and the Court of Appeal: The Commission's Perspective' [2005] Criminal Law Review 937; Annabelle James, Nick Taylor and Clive Walker, 'The Criminal Cases Review Commission: Economy, Effectiveness and Justice' [2000] Criminal Law Review 140.

54 For example, the EU legal order has likewise been criticised for emphasising policing and crime control priorities whilst failing to give corresponding attention to suspects' rights, at least until recently. See Paul Roberts, 'From Extradition to Surrender: EU Criminal Law and Comparative Legal Method' (2014) 53 Howard Journal of Criminal Justice 547; Jacqueline Hodgson, 'EU Criminal Justice: The Challenge of Due Process Rights within a Framework of Mutual Recognition' (2011) 37 North Carolina Journal of International Law and Commercial Regulation 308.

55 See eg JF Nijboer, 'Common Law Tradition in Evidence Scholarship Observed from a Continental Perspective' (1993) 41 American Journal of Comparative Law 299. For further discussion, see Stewart Field, 'Fair Trials and Procedural Traditions in Europe' (2009) 29 Oxford Journal of Legal Studies 365; Richard Vogler, A World View of Criminal Justice (Farnham, Ashgate, 2005); Sarah J Summers, Fair Trials: The European Criminal Procedural Tradition and the European Court of Human Rights (Oxford, Hart, 2007); John D Jackson, 'The Effect of Human Rights on Criminal Evidentiary Processes: Towards Convergence, Divergence or Realignment?' (2005) 68 Modern Law Review 737; 
terminology is preferred, ${ }^{56}$ real procedural differentiation is being described - not least in relation to scientific expertise, which is typically court-appointed in civilian jurisdictions and traditionally not subject to the same degree of adversarial scrutiny and testing that a more lawyerdriven process is capable of generating. This institutional design forestalls some widely discussed problems in common law jurisdictions, ${ }^{57}$ including the potential for partisan bias by experts ${ }^{58}$ (also examined by Stockdale in Chapter 7) and the conundrum of resolving technical disputes between party-instructed experts, ${ }^{59}$ reprising the epistemological issues addressed by Roberts (Chapter 1) and Ward (Chapter 3). Yet if there is one clear lesson to be drawn from comparative studies of criminal procedure, it is that no procedural model enjoys a monopoly of practical wisdom or establishes a universal ideal with no practical downsides. This truism is amply borne out by Vuille's analysis.

Drawing on her own empirical studies of Swiss criminal proceedings, together with more anecdotal data and case studies from the Netherlands, Belgium, Germany and elsewhere, Vuille questions the extent to which the theoretical advantages of traditional procedural models are actually realised in practice. After all, the methodological weaknesses of established forensic science techniques (surveyed by Edmond in Chapter 2) and their newly appreciated limitations of foundational validity and practical application (elucidated by Carr and colleagues in Chapter 5)

Mirjan R Damaška, The Faces of Justice and State Authority: A Comparative Approach to the Legal Process (New Haven, Yale University Press, 1986).

56 Further conceptual complications arise from the progressive 'hybridisation' of procedural models in times of legal cosmopolitanism, such that '[i]t does not necessarily follow from the location of a particular legal system on the continuum between the adversarial and the inquisitorial that it must adopt a particular position as to the role of scientific witnesses': Peter Alldridge, 'Scientific Expertise and Comparative Criminal Procedure' (1999) 3 International Journal of Evidence \& Proof 141, 161. More generally, see Dimitrios Giannoulopoulos, 'Custodial Legal Assistance and Notification of the Right to Silence in France: Legal Cosmopolitanism and Local Resistance' (2013) 24 Criminal Law Forum 291; Mireille Delmas-Marty, 'Reflections on the "Hybridisation" of Criminal Procedure' in John Jackson, Máximo Langer and Peter Tillers (eds), Crime, Procedure and Evidence in a Comparative and International Context (Oxford, Hart, 2008).

57 John R Spencer, 'Court Experts and Expert Witnesses: Have We a Lesson to Learn from the French?' (1992) 45 Current Legal Problems 213.

58 George C Harris, 'Testimony for Sale: The Law and Ethics of Snitches and Experts' (2000) 28 Pepperdine Law Review 1.

59 Anthony Kenny, 'The Expert in Court' (1983) 99 Law Quarterly Review 197. 
must logically extend to forensic science evidence in non-adversary legal systems. Indeed, as Vuille describes, media reports of miscarriages of justice have begun to emerge, ${ }^{60}$ driven by factors - such as faulty evidence processing or flawed interpretations of scientific results - which will be familiar to Anglophone audiences. The role of the defence in scrutinising scientific evidence also needs to be considered, ${ }^{61}$ and in a European context, this means having regard to the influence of the European Court of Human Rights in developing aspects of the right to a fair trial under Article 6 of the European Convention on Human Rights (ECHR). ${ }^{62}$ Vuille stresses the range of institutional variables bearing on the generation - and likely discovery - of miscarriages of justice, which makes like-for-like comparisons between alternative procedural models difficult to construct. As things stand, it is plausible that court-appointed scientific experts, working in well-funded laboratories and with manageable caseloads, are better able to supply objective opinions and reliable evidence to judicial factfinders than party-instructed experts, constrained by administrative structures and financial pressures (reminiscent of the forensic landscape described by Tully in Chapter 4), and testifying to lay jurors in an adversarial trial. In the absence of more systematic empirical data bearing on these questions, Vuille concludes, policy discussion and comparative evaluations of existing practice remain frustratingly speculative.

Completing our baker's dozen, Carole McCartney and Rick Graham in Chapter 13 explore the complexities of transnational scientific evidence, taking a throwaway remark by an Interpol officer - expressing implicit faith in police laboratories - as an ironic provocation to more searching critical investigation. McCartney and Graham build on the arguments and analyses developed in previous chapters, highlighting problematic issues of scientific validity and the interpretational challenges routinely presented by biometric data and other forensic science evidence. However,

60 Also see Chrisje Brants, 'Wrongful Convictions and Inquisitorial Process: The Case of the Netherlands' (2012) 80 University of Cincinnati Law Review 1069,1111 (observing that, '[j] udges may be inclined to give too much weight to expert testimony and forensic evidence (especially true of DNA). ... [I]t is perhaps more problematic that judges will generally have at their disposal the evidence of only one expert').

61 ' $[\mathrm{T}]$ he routine absence of an expert for the defence means that the court is dependent upon its own, often amateur, evaluation of the evidence': ibid.

62 Also see Joëlle Vuille, Luca Lupària and Franco Taroni, 'Scientific Evidence and the Right to a Fair Trial under Article 6 ECHR' (2017) 16 Law, Probability \& Risk 55. 
the context of cross-border information-sharing and judicial reliance on evidence produced in other jurisdictions introduces new dimensions of complexity and practical demands for coordinated action. Establishing broadly compatible rules of criminal procedure and evidence is only the start of it. As well as confronting ancillary legal issues such as harmonising data protection, there is the major regulatory task of developing and agreeing - standards of scientific validity and technical interoperability between forensic scientists in multiple legal systems, with their own distinctive institutional relationships, working practices and professional cultures. The regulatory challenge described by Tully in Chapter 4 is thereby significantly magnified. Yet as McCartney and Graham recount, concerted efforts to promote convergence in European forensic science have been underway for some years now, and they have already progressed further than is widely appreciated. Unlike misdeeds, mishaps and miscarriages of justice, such workaday dimensions of forensic science policy development and implementation do not regularly attract popular media headlines.

The European Union (EU) is the primary locus of these developments. Forensic science is embedded within the EU's policing, security and justice agendas and is actively promoted as "significantly contribut[ing] to making law enforcement more efficient and effective, and to preventing and combating crime'. ${ }^{63}$ Furthermore, the EU supports research and technical development in forensic science, and is aligned with professional organisations such as the European Network of Forensic Science Institutes (ENFSI) ${ }^{64}$ which play a vital mediating role in realising policy ambitions by injecting their technical expertise and practical experience into programmatic interventions. Forensic science is consequently integrated within a formidable institutional phalanx of European legislation, policymaking, governmental agencies, and trans-border cooperation arrangements; and European forensic science will predictably tend to reflect both the strengths and the weaknesses of this broader programme. In the past, EU criminal justice policy has been dominated by policing and law enforcement priorities, but this has been ameliorated somewhat in recent years by a better appreciation of the need to balance crime

63 EU Council, Conclusions on the Vision for European Forensic Science 2020 Including the Creation of a European Forensic Science Area and the Development of Forensic Infrastructure in Europe, 17537/11, 1 December 2011. 64 'The European Network of Forensic Science Institutes (ENFSI) was founded in 1995 with the purpose of improving the mutual exchange of information in the field of forensic science ... as well as improving the quality of forensic science delivery in Europe': http://enfsi.eu/ (accessed 31 January 2018). 
control with respect for procedural rights. ${ }^{65}$ A more holistic approach to safeguarding citizens' 'security' is not advanced by creating a supranational police state with draconian enforcement powers tenuously compatible with the rule of law.

From a specifically UK perspective, 66 Brexit is now energetically stirring the pot. It appears that the British Government would like to keep the existing EU architecture of security, policing cooperation and crossborder mutual judicial assistance substantially in place whilst recalibrating its trading arrangements with the European bloc. ${ }^{67}$ Whether that

65 See European Commission, Towards an EU Criminal Policy: Ensuring the Effective Implementation of EU Policies through Criminal Law, COM (2011) 573 final, 20 September 2011. For contextual discussion, see Estella Baker, 'The Emerging Role of the EU as a Penal Actor' in Tom Daems, Dirk van Zyl Smit and Sonja Snacken (eds), European Penology? (Oxford, Hart, 2013); Christopher Harding and Joanna Beata Banach-Gutierrez, 'The Emergent EU Criminal Policy: Identifying the Species' (2012) 37 European Law Review 758; Kimmo Nuotio, 'European Criminal Law' in Markus D Dubber and Tatjana Hörnle (eds), The Oxford Handbook of Criminal Law (New York, Oxford University Press, 2014); Massimo Fichera, The Implementation of the European Arrest Warrant in the European Union: Law, Policy and Practice (Cambridge, Intersentia, 2011); Estella Baker, 'Governing through Crime: The Case of the Europe Union' (2010) 7 European Journal of Criminology 187; Mireille Delmas-Marty (ed), What Kind of Criminal Policy for Europe? (The Hague, Kluwer International, 1996).

66 Also see John R Spencer, 'The UK and EU Criminal Law: Should We be Leading, Following or Abstaining?' in Valsamis Mitsilegas, Peter Alldridge and Leonidas Cheliotis (eds), Globalisation, Criminal Law and Criminal Justice: Theoretical, Comparative and Transnational Perspectives (Oxford, Hart, 2015).

67 Prime Minister Theresa May has pledged that 'as we leave the EU and forge a new path for ourselves in the world, the UK is just as committed to Europe's security in the future as we have been in the past. Europe's security is our security. And that is why I have said - and I say again today - that the United Kingdom is unconditionally committed to maintaining it. The challenge for all of us today is finding the way to work together, through a deep and special partnership between the UK and the EU, to retain the co-operation that we have built and go further in meeting the evolving threats we face together ... $[C]$ o-operation between our law enforcement agencies means the UK is one of the biggest contributors of data, information and expertise to Europol. ... [T]hrough the Schengen Information System II, the UK is contributing to the sharing of real-time data on wanted criminals, missing persons and suspected terrorists. About a fifth of all alerts are circulated by the UK, with over 13,000 hits on people and objects of interest to law enforcement across Europe in the last year alone': 'PM Speech at Munich Security Conference: 17 February 2018', www.gov.uk/government/speeches/pm-speech-at-munich-security-conference-17february-2018 (accessed 22 February 2018). 
bespoke combination proves to be an inspired negotiating strategy or deluded magical thinking remains to be seen. McCartney and Graham anticipate some potential legal potholes and administrative roadblocks that could frustrate biometric data exchanges and other forensic information-sharing in the near future. Meanwhile, at the more mundane level of routine criminal investigations and prosecutions, continued vigilance will be required to ensure that cross-border investigative measures and their evidential products are compliant with technical standards of scientific validity, national criminal procedure frameworks, and fundamental human rights. The further challenges of verifying experts' interpretational conclusions and testing their application to the instant case, McCartney and Graham's discussion shows, supervene upon these generic preconditions of evidential reliability and procedural justice. It is evident, in short, that police officers, prosecutors, defence lawyers, judges and juries need to know a great deal more about 'imported' forensic science evidence - including matters which in practice are not necessarily easily discovered, verified or determined than its original provenance in a police laboratory. Scholars, researchers and policymakers can barely afford to be less well informed.

\section{RELIABILITY THROUGH REFORM?}

The 13 essays comprising this collection are critical, comparative and multidisciplinary. Although concrete proposals for reform are contained in the following pages, the essays do not speak with a single, unified voice nor do they offer comprehensive solutions to clearly defined problems. This is precisely as it should be, and not only because the volume is intended to reflect and engender further debates between a range of disciplinary and normative perspectives. The methodological foundations, institutional problems and regulatory challenges associated with forensic science evidence (and other expert testimony) are altogether too enduring, complex, dynamic and controversial to be reduced to any agreed, fully particularised, reform agenda. Most of the chapters in this book are concerned predominantly if not exclusively with criminal proceedings, but they tackle questions of expertise and procedural justice with implications for other kinds of legal disputes, across a range of domestic legal jurisdictions, with increasingly cosmopolitan inflexions. The 'problem' or 'issue' cannot even be stated straightforwardly, let alone comprehensively and definitively resolved. 
Again, viewed maturely, this is no cause for regret. Simplicity is often the enemy of practical wisdom, as the philosopher Julian Baggini recently reminds us (in Aristotelian register):

$[\mathrm{P}]$ olitics is incredibly complicated and we must always resist the lure of what appears to be a theoretically clear diagnosis of a problem or a prescription for its solution. ... Radical reform should be possible, but it should usually be piecemeal. It is sheer hubris to imagine that we understand what we are messing with enough to justify anything more wholesale. ${ }^{68}$

What applies to politics in general surely extrapolates in particular to the administration of criminal justice and its deployments of scientific expertise. Just as the project of 'making forensic science fit for justice' describes a journey rather than a destination, ${ }^{69}$ institutional reform is always work in progress, orientated towards new horizons of technological possibility, changing social circumstances and expectations, and revised political demands and constraints.

Even though detailed policy prescriptions will not be offered, the significance of evidential reliability and its contingent relationship with institutional practices are constantly, and diversely, reiterated in the following pages. Whether scientific expertise promotes the ideals of criminal justice or induces their miscarriage is always, in the final reckoning, an empirical question that policymakers in a democratic society neglect at their peril. As a timely intervention into ongoing scholarly debates and contemporary policy discussion, this book aims to deepen understanding of the manifold issues surrounding the reliability of scientific and other expert evidence. It explores the opportunities for further regulatory, institutional and procedural (including evidentiary) reforms and seeks to encourage more enlightened and effective professional practice on the part of lawyers, judges, police investigators, forensic scientists and other expert witnesses.

68 Julian Baggini, The Edge of Reason: A Rational Skeptic in an Irrational World (New Haven, Yale University Press, 2016) 201, 203.

69 Paul Roberts, 'Making Forensic Science Fit for Justice' (2017) 49 Australian Journal of Forensic Sciences 502. 